\title{
El mundo del jurista: hechos, conceptos y soluciones*
}

\author{
Ricardo de Ángel Yágüez \\ Catedrático de Derecho Civil \\ Universidad de Deusto
}

Recibido: 10.11 .08

Aceptado: 14.11 .08

Resumen: El autor, en este trabajo a modo de ensayo, pretende contemplar el Derecho desde la perspectiva de su principal «protagonista», es decir, el jurista. En concreto, lo hace a la luz de los tres elementos que envuelven su quehacer. De un lado, los hechos, esto es, la «historia» que rodea a todo problema jurídico, tanto en la práctica del Derecho como en la profesión académica del mismo. En segundo término, los conceptos, palabra con la que el autor ha querido resumir lo que habitualmente conocemos como la dogmática jurídica, esto es, la reflexión científica con la que el jurista «opera» para llegar a un desenlace. Y en tercer lugar, el desenlace mismo, que el autor denomina «soluciones». Se trata de un análisis que toma como puntos de mira la existencia y la experiencia que el jurista -todo jurista- vive. De ahí la alusión a las inquietudes que pueblan el mundo de quien desarrolla cualquier actividad profesional en Derecho.

Palabras clave: El Derecho: su teoría y su práctica. El jurista y su «mundo». Hechos y conceptos en el estudio y en la aplicación del Derecho. La solución de los problemas jurídicos.

Abstract: The author in this essay aims to examine the Law from the point of view of its «main character», i.e., the jurist. In doing so, he takes into account the three main elements related to the jurist's work. Firstly, the facts, i.e., the story behind every legal problem, in the legal practice as well as in the academic profession. Secondly, the concepts, as the word by which the author wants to summarize what we usually know as the legal dogmatic, i.e., the scientific thoughts that the jurist uses in order to get to a final solution. And finally, the outcome itself, that the author calls «solutions». The present is an analysis that uses as targets the existence and the experience that the jurist-every jurist-does experience. That is why there is a mention to the worries that are common to everyone who develops any legal professional activity.

Key words: The Law: its theory and practice. The jurist and his «world». Facts and concepts relating to the study and application of the Law. The solution to the legal problems.

* Este texto es la versión completa de la lectio brevis desarrollada por el autor en el acto de su investidura, el 21 de octubre de 2008, como Doctor honoris causa por la Universidad de Buenos Aires. El propio autor ha decidido mantener la salutación con la que comienza el trabajo, a pesar de que el texto leído en aquel acto fue, naturalmente, más reducido que el que ahora se publica. 
Sumario: I. A modo de introducción.-II. Hechos.-III. Conceptos.-IV. Soluciones

Excelentísimo Señor Rector, Doctor Hallú, Ilustrísimo Señor Decano de la Facultad de Derecho, Doctor Alterini, muy respetables autoridades académicas, distinguidos Profesores, queridos colegas, señoras y señores

1. En la tradición académica, suele denominarse lectio brevis a las palabras del designado Doctor honoris causa. Y lectio, antes de su acepción común en español (lección), tuvo la de lectura o acción de leer. Por eso, se me permitirá que, en efecto, lea el texto que he preparado para este acto. Ojalá su resultado se corresponda con el esmero que he puesto en su redacción.

Debo confesarles que el género de la lectura de lo escrito por mí no me produce particular entusiasmo, aunque forma parte del «ritual» universitario, para casos como el presente, en muchos países; sobre todo, europeos. Me gusta más la viveza del discurso sin papeles, siempre que no se caiga en el vicio de la improvisación ni se inspire en el auditorio ninguna sensación de desconsideración o falta de rigor en lo que se dice.

Pero me someto gustoso a la disciplina, casi ascesis, de leer.

Como no podía menos de ser, le he dado muchas vueltas a la cabeza sobre lo que yo podía decir en un acto tan significativo en mi vida como es el presente.

Primero, por el motivo: la recepción de una distinción que me abruma, porque supera todas las expectativas que yo habría podido albergar en mi dilatada y afanosa, sí, pero en realidad modesta dedicación al Derecho; en la cátedra, en lo que he escrito y en la defensa de intereses ajenos como abogado.

En segundo término, por el lugar: una Universidad, la de Buenos Aires, que tantos maestros ha tenido y tiene (y seguro que seguirá teniendo) en todos los saberes. Los de la Facultad de Derecho, en concreto, han sido y son espejo en el que mirarse juristas de todas las latitudes. No puedo silenciar que en ella encontraron refugio académico tantos profesores españoles después de nuestra terrible guerra civil.

Y había un tercer motivo para mis cavilaciones sobre qué decir hoy aquí. Ciertamente, el más comprometedor. Me refiero al auditorio, nutrido de ilustres juristas que me honran con su presencia, en patente y emotivo signo de amistad.

Pero estas fundadas inquietudes pasan a segundo plano ante otro sentimiento que tengo y que expreso en palabras breves pero muy de corazón. Es el agradecimiento a los órganos de gobierno de la Universidad, y de su 
Facultad de Derecho, por haberme otorgado el honor de ser Doctor honoris causa por esta Universidad de Buenos Aires. Muchísimas gracias por su generosidad.

Muy particular gratitud al Profesor Alberto Bueres, por su afectuosa laudatio. Le es aplicable lo de «abundantia cordis», que en este caso no sería abundancia sino exceso. Y no menor por haber sido quien, con su propuesta, impulsada luego por el Decano Profesor Alterini, dio lugar a la honrosísima designación.

2. Y se me permitirá otra concesión al sentimiento, al aprovechar esta ocasión para subrayar mi larga y profunda relación con Argentina y con sus gentes. Este viaje es mi decimocuarto a su bello país. Los anteriores, menos uno, fueron por razones académicas. Desde hace 25 años, para participar en un congreso en Salta.

Argentina me ha dado muchos y muy buenos amigos, sobre todo en sus Universidades. Y de forma muy especial, en la de Buenos Aires, en la que he tenido el honor de intervenir en Jornadas Nacionales, congresos y cursos. También se me concedió la distinción de participar en Jurados para el nombramiento de Profesores.

Muy singular emoción me produce el recuerdo del Profesor Roberto López Cabana, con quien tan gran amistad me unió y que tan pronto nos dejó.

\section{A modo de introducción}

3. Para intentar una digna salida del trance en que me encuentro, me he refugiado en el lenguaje.

El nombre de lectio brevis no encuentra problema en el adjetivo. Sin duda, obedece a una razón caritativa; para el que escucha, pero también para quien habla.

Más inquietante (esta vez para el que habla) es lo de lectio. Puede entenderse en el sentido hoy más natural: conocimiento que transmite el profesor a sus discípulos. Pero enseguida excluí esta interpretación. Ni siquiera se me ocurriría la «ilusión» de ser maestro en nada para ustedes, que tienen la amabilidad de escucharme.

Por eso, decidí escudarme en la originaria acepción latina de lectio, que no fue la de lectura, o la antes citada de «lección», sino la de «elección» o «recogida ${ }^{1}$.

${ }^{1}$ De lego, legere, «recoger», «reunir», «amontonar». El significado «leer» es tardío y figurado: SEgura Munguía, Santiago, Nuevo diccionario etimológico latín-español y de las voces derivadas. Universidad de Deusto, Bilbao, 2001. De la misma forma, para lego y para lectio, en Oxford Latin Dictionary, Clarendon Press, Oxford, 1968. 
Porque, en efecto, descartado un discurso dogmático o doctrinal, he optado por que mi lectio no intente ser una «enseñanza», sino la reunión de un conjunto de reflexiones sobre extremos que forman parte de la existencia del jurista. En mi caso (pobre mérito, porque deriva simplemente del calendario), algo que he podido percibir en más de dos tercios de mi vida.

Quiero decir que no se va a tratar de una exposición sobre un concepto, una institución, un problema, sino de un discurso «existencial»; o, si se quiere, «experiencial», aunque no en el sentido que se da a esta palabra en Psicología.

De ahí el título de estas palabras: el mundo del jurista.

Pero lo que digo no se refiere a mí, desde luego, ni a mis conocimientos o a mis ignorancias, ni a mis posibles aciertos o a mis seguros desaciertos. Quiero aludir a lo que cualquier jurista conoce y palpa cada día, precisamente porque es «su mundo».

Al hablar del «mundo del jurista», me refiero a todo jurista. Los paradigmas son, ciertamente, el juez, el abogado y el profesor (que vive el Derecho justamente porque lo profesa), pero lo que digo es aplicable por igual a cualesquiera profesiones jurídicas. Entre ellas, cada día más importante, la del funcionario jurista, de quien depende muchas veces que una determinada situación se convierta o no en conflicto; y de quien depende, ciertamente, que la Administración actúe ajustada a Derecho².

De acuerdo con lo que antes he dicho sobre lo que puede ser una lectio brevis, he decidido dividir mis consideraciones en tres aspectos: hechos, conceptos y soluciones. Estos tres «ingredientes» conforman, a mi juicio, el mundo del jurista.

\section{Hechos}

4. Me parece sugerente, para este apartado y para el que sigue, un conocido texto romano (de Ulpiano) que todos aprendimos nada más entrar en la Facultad. Aquel que decía: «Iuris prudentia est divinarum atque humanarum rerum notitia, iusti atque iniusti scientia $»^{3}$. Subrayo el orden de los dos inci-

\footnotetext{
${ }^{2}$ En el caso de España, tendrían que ser objeto de particular mención los notarios y los registradores de la propiedad, que desempeñan muy relevante función en la llamada seguridad jurídica preventiva. En relación con el funcionario jurista, es interesante recordar una especie de «sospecha» que se arrastra legislativamente. No está de más señalar que el artículo 103.1 de la Constitución Española considera necesario recordar el deber de pleno sometimiento a la ley y al Derecho que incumbe a las Administraciones Públicas, repitiendo para ellas la cláusula general del artículo 9.1 de la misma Ley Fundamental.

${ }^{3}$ Digesto, 1, 1, 10, 2. Parece que la frase tiene su origen en Cicerón, De officiis, I, 43, 153, pasaje en el que el brillante orador, que no jurista, dijo: «Mas esta sabiduría, que he dicho ser la primera y principal, es la ciencia de las cosas divinas y humanas, en la cual se contiene toda la relación de los hombres con los dioses, y la sociedad entre sí mismos» (traducción al español bajo el título Los oficios de Cicerón, Sociedad Española de Librería, Madrid, 1928, tomo I, p. 129).
} 
sos del predicado, que probablemente no fue casual: primero las cosas, después la ciencia.

No sería incorrecto traducirlo diciendo: «conocimiento de todo lo divino y lo humano, y ciencia de lo justo y de lo injusto» ${ }^{4}$. No obstante, se me permitirá un apunte filológico, con cuidado de no caer en intrusismos, para tratar de desentrañar lo que aquel pasaje pudo querer decir. Creo que no es inoportuno hacerlo, porque recurrir a acepciones tardías en textos clásicos puede llevar a que se pierdan matices de la admirable lengua latina. Lengua que, como ustedes ven (mejor dicho, oyen), pronuncio en la forma que aprendí en el excelente Bachillerato español de mis tiempos, hoy lamentablemente desterrado por aprendices de brujo de la Pedagogía ${ }^{5}$. Es decir, no uso la fonética germánica del latín, y tampoco la vaticana.

5. Hace ahora 31 años, oí la lección inaugural pronunciada en la Universidad de Deusto por un sabio jesuita, físico y eminente filósofo de la ciencia, el Profesor Jaime Echarrí ${ }^{6}$. Dijo algo que me llamó la atención y que siempre he recordado ${ }^{7}$.

Puso de relieve cómo los átomos no pudieron ser vistos, ni tocados, ni olidos, por Leucipo ni por Demócrito. Eran cosas «no de este mundo», es decir, del mundo de los sentidos; eran cosas del «mundo del físico». Aquellas «partículas» comenzaron a crecer en número de forma sorprendente. Primero el protón, el electrón, el neutrón y el fotón. A partir de comienzos del siglo XX, la lista de «partículas» siguió aumentando de manera espectacular ${ }^{8}$.

Quiero, con todo esto, destacar que también en el Derecho hay cosas «de este mundo»y otras que no lo son.

Me refiero ahora a las primeras, que son las que vemos, oímos y tocamos. En suma, las que «vivimos» ${ }^{9}$.

${ }^{5}$ En El Digesto de Justiniano, de A. D’ors, F. Hernández-Tejero, P. Fuenteseca, M. García-Garrido y J. Burillo, Aranzadi, Pamplona, 1968, tomo I, p. 46, se traduce: «La jurisprudencia es el conocimiento de las cosas divinas y humanas, la ciencia de lo justo y de lo injusto».

${ }^{5}$ Algunos congéneres, muchos de ellos indocumentados y ágrafos, parecen hoy empeñados en arruinar el plan de estudios de nuestra Licenciatura en Derecho. En la que, por cierto (¿casualidad?), formaron sus mentes tantos eminentes juristas como España ha tenido y tiene.

${ }^{6}$ Echarri Goicoechea, Jaime, El mundo del físico, Universidad de Deusto, Bilbao, 1977, 33 páginas.

${ }^{7}$ Como se ve, me inspiro en su imaginativo título; pero, también es evidente, en nada más.

${ }^{8}$ Cuando el Profesor Echarri hablaba, esas partículas, incluidas las «resonancias», eran más de 100 , y algunos las elevaban a más de 200. Pero ninguna de ellas era «de este mundo», esto es, del mundo de los sentidos.

${ }^{9}$ Sobre esto escribió páginas de valor permanente DíEz-PicAzo, Luis, Experiencias jurídicas y teoría del Derecho, Ariel, Barcelona, citado sobre su $3^{\text {a }}$ ed., 1993. Principalmente, capítulo XI, «Aplicación del Derecho», pp. 221 ss. 
La primera, la que, además de vivir, «sentimos» (con el significado de «experimentar una impresión»), es el conflicto.

El conflicto es algo inherente a la convivencia ${ }^{10}$. Y, desde nuestro punto de vista como juristas, es una de las razones de ser del Derecho. Hace muchos años que escribí sobre él (el Derecho) como instrumento para poner un final razonable a las controversias.

Se me permitirá un toque de exageración cuando digo algo que he pensado alguna vez, aunque intentando pronto deshacerme de la idea: que no es tanto cuestión de que la sociedad tenga o no jueces dotados de un gran saber jurídico, sino de que los ciudadanos sepan que sus conflictos van a tener «una solución» (la que sea), decretada por un juez verdaderamente neutral e independiente.

Y no hace mucho, el maestro Luis Díez-Picazo dijo, a mi juicio con finura y realismo, que el Derecho no es para hacer a los hombres mejores o más felices, sino para pacificar la convivencia y hacerla más llevadera ${ }^{11}$. Todos entendemos lo que Díez-Picazo quería decir cuando hablaba de «hacer mejor o más feliz» a la persona. Porque, en efecto, sería mucho pretender que el Derecho dispensase «felicidad» en sentido estricto. No obstante, me parece que no es infundado decir, y así lo hago, que del Derecho (como orden jurídico) deriva, para cada uno de nosotros, la tranquilidad o la confianza de esperar que nuestra existencia no se vea sujeta, normalmente, a sobresaltos no esperables, ni al capricho o al poder de otro. Saber que el préstamo que concertamos está sujeto a unas reglas de considerable precisión, o que el conductor de un vehículo se detendrá en el stop de una calzada que confluye con aquella por la que uno está circulando, sí otorgan al individuo una cierta dosis de felicidad, siquiera en el sentido más amplio de la palabra.

Por otro lado, la afirmación del Profesor Díez-Picazo quizá esté un tanto escorada hacia el que llamaríamos Derecho patrimonial, puesto que en el terreno del Derecho de la persona parece claro que sí es admisible hablar de una felicidad como objetivo o producto del Derecho. No debe olvidarse, sin ir más lejos, que la desaparición de la esclavitud o la consagración de la no desigualdad por razón de sexo o de raza, por ejemplo, fueron obra del Derecho, entendido como la ley, sin que deban desorientarnos los presupuestos políticos, ideológicos o sociales que condujeron a ambas conquistas.

6. El conflicto entraña en ocasiones hechos físicos (una lluvia intensísima en lugar habitualmente árido -problema de seguros-, la colisión de dos automóviles -responsabilidad-, o incluso el mero paso del tiempo -ser o no

${ }^{10}$ Podría considerarse, incluso, que es una condición positiva de la prosperidad y del crecimiento de la sociedad pluralista. Una sociedad absolutamente desconflictivizada llevaría a lo que Galbraith denominó un estado de paz indeseable del todo.

${ }^{11}$ En una breve pero jugosa entrevista en la revista Abogacía Española, número 30, julio-setiembre 2004, pp. 46-49. 
ser mayor de edad, hábil para contratar válidamente-). Otras veces se trata de conductas (ingratitud que justifica la desheredación, comportamiento del trabajador merecedor del despido, actos del Gobierno que motivan una moción de censura). En otros casos, son propósitos exteriorizados, sin necesidad de consumación (el delito frustrado, la objeción de conciencia) ${ }^{12}$.

Todo esto, parafraseando al Profesor Echarri, son cosas «de este mundo».

Y si convenimos -será muy difícil no hacerlo- en que los conflictos, en plural, son los hechos que principalmente justifican la existencia del Derecho y de los juristas, no parece posible hablar del «mundo» de estos últimos si no es poniendo de relieve una circunstancia harto conocida por todos nosotros.

Me refiero al formidable volumen de controversias jurídicas, característica de nuestros días. Lo que a veces llamamos enorme litigiosidad, o también conocemos como extraordinaria «judicialización» de la vida social.

Un dato elocuente es el notable incremento de los órganos judiciales, de todo orden y grado, que sobrepasa con creces -al menos en España- la pura tasa de crecimiento demográfico. Diríase que hay demasiados pleitos.

No es momento ni lugar para someter a análisis este fenómeno, pero parece claro que contribuyen a él varios factores. De un lado, el desarrollo cultural de la población y la progresiva democratización de nuestras sociedades, determinantes, a mi juicio, de un aumento considerable del sentido, en cada ciudadano, del «tengo derecho a». También contribuye al fenómeno, según creo, el hecho -que ha sido objeto de estudio en el terreno de la Psicología social- de que hoy la persona no se resigna tanto como en el pasado a soportar sus quebrantos como si fueran cosas de la providencia. Más aún, y así lo he escrito en algún otro lugar, parece como si, en los tiempos que corren, todos sintiéramos la tentación de creer que «otro» es el culpable de todos nuestros males; o, simplemente, de todas nuestras contrariedades ${ }^{13}$. Y acaso pudiera sostenerse que -como paradoja-, también el aumento del nivel de vida contribuye a una mayor conflictividad.

\footnotetext{
${ }^{12}$ La noción de hecho adquiere hoy dimensiones que la convierten en un concepto jurídico indeterminado. Piénsese en los hechos del siquismo interior de la persona, a los que el jurista llega por obra de unos indicios que no facilitan una subsunción exacta en el tipo de la norma jurídica. El principio pro reo, no es tanto una expresión humanitaria del Derecho penal, cuanto la explícita confesión de la imposibilidad de conseguir una versión exacta y exhaustiva de los hechos relativos a la culpabilidad del sujeto. Por otro lado, los hechos han pasado, de ser el mero supuesto para la aplicación de las normas, a ostentar la cualidad de realidades sociales, a las que hay que estar para que el jurista practique una revisión de las normas jurídicas similar a la que, en otro terreno, autoriza el juego de la cláusula rebus sic stantibus.

${ }^{13}$ Esto es particularmente perceptible, según entiendo, en el caso de los daños, esto es, en el de lo que hemos venido denominando responsabilidad civil o responsabilidad extracontractual.
} 
Cabría preguntarse si el incremento de la litigiosidad tiene que ver, a modo de consecuencia, con el elevado número de abogados de ciertas sociedades. Es probable que sea así. En todo caso, el «fenómeno» al que me acabo de referir podría enlazarse fácilmente con una pregunta de la que aquí no me puedo ocupar. Aludo a la eterna cuestión sobre la «función» de los juristas, y en concreto de los abogados, en cualquier sociedad. Y de ahí no hay más que un paso a otra pregunta nada nueva: ¿somos demasiados los juristas? $\mathrm{O}$ a otra de todavía mayor calado: ¿en qué somos útiles al mundo que nos rodea?

Lo cierto es que la multiplicación de los conflictos judiciales está conduciendo a la búsqueda de alternativas al pleito, introduciendo así un factor nuevo en la vida del jurista ${ }^{14}$.

7. Vuelvo a la definición de Ulpiano que he adoptado como punto de partida.

Me parece que sería un anacronismo creer que, cuando el texto en cuestión utilizó la palabra scientia para referirse a «lo justo y lo injusto», lo hiciera dando al vocablo el significado en el que hoy lo entendemos. Desde Kant ${ }^{15}$ y Fichte entre los filósofos, y desde la Pandectística (principalmente, sobre la base de Savigny, Ihering, Gierke y Windscheid) entre los juristas. Es decir, el sentido de cuerpo de doctrina metódicamente formado y ordenado, que constituye una rama particular del saber humano; o el de conjunto de conocimientos obtenidos mediante el razonamiento, sistemáticamente estructurados y de los que se deducen principios y leyes generales ${ }^{16}$.

${ }^{14}$ Está por ver qué resultados producirán la conciliación y la mediación. Por ejemplo, en los ámbitos que parecen más propicios: los conflictos familiares y los laborales.

${ }^{15}$ Es el Kant para el que la palabra «Derecho» tenía un doble significado: uno general y otro estricto o puro (antecedente de la denominación de «Derecho puro» de Kelsen). El primero tiene sentido ético, es captado por la conciencia subjetiva y no es determinable objetivamente de modo científico; pero el segundo es el propiamente jurídico, según Kant lo entendió. Puede encontrarse un desarrollo de esto (aunque sea un extremo opinable) en VALLET DE Goytisolo, Juan Berchmans, en Las definiciones de la palabra Derecho y los múltiples conceptos del mismo, Real Academia de Jurisprudencia y Legislación, Madrid, 1998, pp. 67 ss. La lectura directa puede hacerse en KANT, Immanuel, La Metafísica de las Costumbres, estudio preliminar y notas de CoRTINA ORTS, Adela, y Conill SANCho, Jesús, Tecnos, Madrid, 1989. Sobre todo, en la Primera Parte, «Introducción a la doctrina del Derecho».

${ }^{16}$ No obstante, el carácter de ciencia, aplicado al saber jurídico, se atribuye a veces al pensamiento de juristas anteriores a la Pandectística. El apelativo de «ciencia» derivaba, sin duda, del entronque entre el Derecho y la Filosofía moral (de acuerdo con la terminología de los protestantes), o la que los católicos, sobre todo los españoles, denominaban Teología moral. Así, Sumner MaINe, Henry (El Derecho antiguo considerado en sus relaciones con la historia de la sociedad primitiva y con las instituciones modernas, traducción de A. Guerra, Madrid, 1893, reproducción en facsímil de Editorial Cívitas, Madrid, 1994, p. 94), no dudó en hablar de «la ciencia» de las dos «escuelas», al referirse a la brecha abierta poco después de la Reforma: la de los casuistas, católicos todos y monjes casi todos, y los escritores unidos por descender intelectualmente de Hugo Grocio. 
Es más razonable pensar que scientia quería decir, entonces, «conocimiento» o «saber». Se trataría del conocimiento de las normas de Derecho y de las opiniones de los juristas. Sciens sería «el que sabe», el «experto», no lo que hoy llamaríamos un «científico» ${ }^{17}$.

Pero es a la primera parte del texto a la que ahora quiero referirme, esto es, al «divinarum atque humanarum rerum notitia». Y es para poner de manifiesto que notitia significaba «conocimiento», pero no en el sentido de saber como un resultado, sino en el de acción de conocer; quiere decir, una actitud. O si se prefiere, una disposición (a «conocer»), fácilmente trasladable a la necesidad de hacerlo.

Porque notitia, a diferencia de la scientia, no concuerda con el verbo cognoscere $^{18}$, ni parece que significó propiamente «conocimiento». Su origen está en el verbo latino nosco, infinitivo noscere, que quiere decir «aprender a conocer» ${ }^{19}$. Por eso, el nosce te ipsum no equivale a «conócete a ti mismo», como a veces se dice, sino «aprende a conocerte».

Conocer (en el sentido de «aprender a conocer») todo lo divino y humano, es una de las tareas más apasionantes del jurista. En su forma de hablar, el texto romano, según creo, quería decir algo que vivimos todos los días.

El jurista se ve permanentemente en la necesidad de conocer algo de otros saberes. ¿Cuántas veces se ve obligado a entender conceptos y técnicas de la Economía, de la Medicina, de la Física, de la Arquitectura; o incluso, pongamos por caso, de la Psicología, de la Sociología o de la Gramática?

${ }^{17}$ D'ORs, Álvaro, en Una introducción al estudio del derecho, Rialp, Madrid, 1963, p. 20, escribió: «El derecho, mejor, la prudencia del derecho, saber de los jurisconsultos, es ciencia y técnica de lo justo y de lo injusto. La ciencia se refiere a qué y la técnica al cómo, pero ambas se compenetran. La contraposición ciencia-arte, aplicada al derecho, puede resultar desorientadora. Juega ahí un equívoco semántico. Scientia y ars, en griego epistéme y téchne, no son antitéticos. El 'arte' o 'técnica' es el modo de aplicar y comunicar la ciencia; se debe a la cultura helenística el desarrollo de ese aspecto más práctico -de aplicación o enseñanza-; pero no se trata de una sustitución, pues si una ciencia sin técnica puede resultar excesivamente teórica y difícil de comunicar, una técnica sin ciencia es un absurdo. Lo que sí puede darse, y de hecho se ha dado en la historia, es una separación profesional entre teoría y práctica del derecho. Pero el derecho es necesariamente teoría y práctica a la vez, ciencia y arte». Por otro lado, añado yo, «ciencia» es una palabra que aparece en español ya avanzado el siglo XIII, según los diccionarios de autoridades, pero también con el significado de conocimiento, nada más. En Introducción histórica al Derecho romano, de Churruca, Juan, y MentXaka, Rosa, $9^{\text {a }}$ edición, Universidad de Deusto, Bilbao, 2007, p. 102, se lee: «A través de un largo proceso intimamente relacionado con la evolución de la cultura en Roma, la profesión de jurista (iuris peritus, iuris prudens = conocedor práctico del derecho) se fue perfilando con unas características peculiares. Con ello fue formándose progresivamente una ciencia práctica del derecho. Para designar esa ciencia práctica los romanos utilizaron preferentemente el término iuris prudentia».

${ }^{18}$ Que, en efecto, significa conocer (por la inteligencia o por los sentidos).

${ }^{19}$ En Oxford Latin Dictionary, cit., se dice de nosco que es, entre otras cosas, «conseguir saber», «familiarizarse uno» con algo. En su forma arcaica, gnosco. 
En mi experiencia, pocos han sido los casos en los que esto no haya ocurrido. Entender el «misterio» de cómo se determina el valor de una empresa, o cuánto «vale» la vida de una persona, cuándo un vicio de construcción es fruto de un proyecto defectuoso y no de la acción de edificar, o saber cuáles son las causas posibles de un paro cardíaco, han sido cuestiones que he tenido que «entender». Por boca, naturalmente, de un economista, de un actuario, de un arquitecto o de un cardiólogo ${ }^{20}$.

Creo que no me desmentirán los abogados que me escuchan, cuando afirmo que en los procesos judiciales, en concreto, el jurista (incluyo al juez) tiene que dedicar mucho más tiempo, y mucha más energía, a establecer los hechos («lo que ocurrió») que a la argumentación jurídica en defensa de una tesis. A mí me inspiran más admiración las sentencias muy cuidadosas en la descripción de los hechos que las «técnicamente» brillantes ${ }^{21}$.

Los hechos son ahora, casi siempre, acontecimientos en los que tienen mucho que decir las ciencias de la naturaleza. Están lejos las realidades constitutivas de los supuestos de hecho de nuestros códigos decimonónicos, sobre todo en materias de carácter patrimonial. En ellos, los hechos dimanaban de una rudimentaria agricultura, de una industria muy próxima a la artesanía y de una sociedad aislada, invertebrada y gobernada por el individualismo.

No deja de ser significativo que un concepto hoy muy común en Derecho, el de «estado de la ciencia» («state-of-the-art» en la terminología anglosajona), fuera acuñado por juristas ${ }^{22}$.

${ }^{20}$ En un reciente trabajo sobre los posibles efectos nocivos de los campos electromagnéticos derivados de antenas de telefonía móvil o de conducciones eléctricas (DE ÁNGEL YÁGÜEZ, Ricardo, «De nuevo sobre la responsabilidad por inmisiones electromagnéticas: el 'estado de la ciencia' como solución jurídica», en el libro colectivo La nueva regulación eléctrica. VII Jornadas Jurídicas del Sector Eléctrico, Civitas, Madrid, 2002, pp. 349-410), tuve que introducirme en el altamente «misterioso» mundo de las radiaciones no ionizantes, de las «frecuencias», de las «potencias», de los teslas, de los miniteslas, de los microteslas y aun de los nanoteslas. Pero la cuestión no es lo que me sucedió, sino lo que inexcusablemente ocurrirá a todo aquel jurista que se ocupe de examinar cuándo y cómo esos campos electromagnéticos pueden ser una forma de «inmisión», como hasta ahora $-\mathrm{y}$ en ciertos casos desde algún texto romano clásico- hemos entendido que lo son (inmisiones) los humos, los ruidos, las vibraciones, los olores, o incluso la aparentemente inofensiva luminosidad en nuestras calles.

${ }^{21}$ Sentís Melendo, Santiago, escribió, a mi juicio con acierto, que «necesitamos jueces factistas más que juristas»: La prueba, EGEA, Buenos Aires, 1978, p. 281.

${ }^{22}$ En la bibliografía en español al respecto, puede verse la monografía El riesgo de desarrollo: un supuesto paradójico de la responsabilidad por productos, de PRIETO MOLINERO, Ramiro José, Dykinson, Madrid, 2005, que recoge parte de la tesis doctoral del joven jurista argentino, tesis que tuve el honor de dirigir. El «estado de la ciencia», concepto muy próximo pero no idéntico al de «riesgos del desarrollo», fue citado por vez primera, según parece, en el caso Day v. Barber-Colman Co. (1953), que trató sobre los daños y perjuicios ocasionados a la actora al caérsele una puerta corrediza que estaba instalando. 
No es que el estado de la Medicina, o de la Biología, por ejemplo, sean ignorados por médicos o biólogos, pues es frecuente, entre ellos y otros profesionales, que se aluda a la literatura científica existente cuando se pronuncian o actúan.

Lo que ocurre es que la expresión como tal («estado de la ciencia») se ha instalado con este nombre en el mundo del Derecho, para establecer, en ocasiones, causas de exoneración de responsabilidad. Así sucede en España, por ejemplo, en dos leyes de máxima importancia ${ }^{23}$.

Pero es que, además, la misma noción de estado de la ciencia se utiliza cada día en el mundo del Derecho, cuando se trata de determinar, por un perito, bien sea «de parte», bien sea designado por el tribunal, si la actuación de un profesional demandado se ajustó o no a las reglas de lo que tradicionalmente hemos conocido como lex artis.

Y todo ello, naturalmente, teniendo en cuenta que el propio Derecho es un ars, entendida la palabra española «arte» como habilidad para hacer algo. Ya en el Digesto ${ }^{24}$ se definió el ius como ars boni et aequi, «técnica de lo bueno y de lo justo» ${ }^{25}$.

8. El «mundo» de los hechos, sin embargo, entraña una servidumbre para el Derecho; una circunstancia que a veces lo aleja sideralmente de la justicia, entendida esta palabra como «razón» o «solución ajustada». Es una servidumbre a la que es particularmente sensible quien confió en el éxito de su pretensión, precisamente, porque la consideraba justa (él sí conocía los hechos, aunque luego no pudiera probar alguno decisivo).

Me refiero, claro está, a la necesidad de probar los hechos. Es el «probar o sucumbir», que dice uno de los viejos apotegmas del Derecho procesal ${ }^{26}$.

Un muy conocido aforismo jurídico («da mihi factum, dabo tibi ius») engarza idealmente la respuesta del juez (la aplicación del ius) con una premisa que sólo tiene valor como regla teórica o académica: la de que quien pide justicia ha probado todo lo que aconteció. De ahí el «da mihi factum».

Lo que no veo tan claro es la segunda parte del apotegma, esto es, el «dabo tibi ius», que, vinculado a otro aforismo tan frecuentemente invocado

${ }^{23}$ Se trata de la Ley que regula, entre otras cosas, la responsabilidad patrimonial de las Administraciones Públicas, y de la Ley de responsabilidad por daños causados por productos defectuosos. Esta última se encuentra, desde el año 2007, incluida en el texto refundido de la Ley general para la defensa de los consumidores y usuarios.

${ }^{24}$ D. $1,1,1$ pr.

${ }^{25}$ Así lo traducen D'ors et al., en El Digesto..., cit. D'ORS, Derecho privado romano, Ediciones Universidad de Navarra, Pamplona, $10^{\text {a }}$ ed., 2006, p. 48, alude a la concepción del ius como «disciplina de la equidad». El autor insiste en que scientia equivale a ars (la disciplina ordenada y discible, esto es, susceptible de aprenderse).

${ }^{26}$ A esta especie de «máxima» se refirió, en varios lugares de su obra, sobre todo pp. 16 ss y 47 ss, MuÑoz SABATÉ, Luis, Técnica probatoria. Estudios sobre las dificultades de la prueba en el proceso, $4^{\text {a }}$ ed., Editorial Praxis, Barcelona, 1993. 
(el «ius novit curia»), no es sino la expresión de un objetivo, de un ideal, de una aspiración ${ }^{27}$.

Evidentemente, este segundo aforismo es un modo de hablar. Supone a un jurista (en este caso el juez) que conoce todo el Derecho, y que por ello va a acertar en su decisión.

Nada más lejos de la realidad. Afirmar que el tribunal conoce el Derecho es una entelequia. $\mathrm{O}$ si se quiere, en palabra menos irónica, una aporía.

Se suele decir que la ley procede del pueblo, pero éste no la conoce. Y tampoco los propios juristas, entendiendo conocer en su sentido estricto.

La «legislación motorizada» de nuestros días conduce a que el Derecho que el tribunal «conoce» sea, en cada caso, y muchas veces, el que las partes, con mayor o menor acierto, invocan ante aquél. Y vence el que convence a un juez que, dicho con todo respeto, es con frecuencia como el espectador de un partido de tenis.

El año pasado, el 2007, el Parlamento español dictó 72 Leyes, a las que hay que unir 11 Reales Decretos-Ley y 2 Reales Decretos-Legislativos. Pero lo que importa es que el Gobierno promulgó 1.768 Decretos. Y sería muy laborioso contar cuántas disposiciones reglamentarias emanaron de los Ministerios y autoridades inferiores ${ }^{28}$. Un conocido repertorio de legislación español (no oficial), alcanzó, el mismo año 2007, el asombroso número de 11.749 páginas, en 4 tomos de apretada letra, y casi sólo para disposiciones procedentes del Estado.

Por ello, quizá no fuera excesivamente extravagante decir que las reglas legales de inferior rango normativo no son Derecho, sino «hechos». Por ello, excluidas del ius novit curia ${ }^{29}$.

Si a ello unimos la desafortunada técnica normativa propia de nuestros días $^{30}$, el «mundo» del jurista consiste ahora, en buena medida, en averiguar qué disposición debe invocar, qué parte de ella está todavía en vigor y cómo puede conciliarse con otras normas de desarrollo o afines a la que tiene entre sus manos. En suma, en la actualidad es tarea ímproba para él, no ya el saber

${ }^{27}$ Procede advertir que el dabo tibi ius ha sido recientemente robustecido por el principio pro actione.

${ }^{28}$ Y no digamos de los Parlamentos y de las Administraciones autónomas.

${ }^{29}$ Tengo referencia, aunque no conocimiento directo, de que un juez de la ciudad en la que resido imponía a los abogados la prueba -mediante fotocopia de la publicación oficialde las normas «inferiores» a las que me refiero.

${ }^{30}$ Merece leerse el breve, demoledor y documentado artículo de Tomás-Ramón FERNÁNDEZ, titulado «De la banalidad a la incoherencia y la arbitrariedad. Una crónica sobre el proceso, al parecer imparable, de degradación de la Ley», en El cronista del Estado social y democrático de Derecho, número 0, octubre 2008, pp. 38-45. Con mucho mayor detalle, el libro del mismo autor De la arbitrariedad del Legislador. Una crítica de la jurisprudencia constitucional, Civitas, Madrid, 1998. Y en punto a la «buena forma» de legislar, vid. «El canon clásico de la técnica legislativa», capítulo I de Técnica normativa, de MARTínEZ-CARDós RuIz, José Leandro, Universidad Complutense de Madrid, Madrid, 2002. 
Derecho, sino intentar moverse con alguna soltura en la maraña normativa que nos envuelve.

Y si decimos -luego volveré sobre esto- que uno de los objetivos del jurista es predecir o vaticinar, y añadimos que la seguridad jurídica tiene uno de sus apoyos en la previsibilidad de las soluciones, creo que la descripción del «mundo» del jurista quedaría manca si no hubiera hecho alusión al fenómeno al que acabo de referirme ${ }^{31}$.

9. La seguridad jurídica, a la que tanto relieve damos los juristas (según el artículo 9 de nuestra Constitución es un principio garantizado por ella misma), lleva, al menos en parte, a un buen número de «hechos» que lo son porque lo dice la ley. Por eso han necesitado de tantas «explicaciones» por parte de la doctrina jurídica. A título de ejemplos, basta recordar algunos.

Casos en los que por hechos entendemos la situación actual, o más reciente, no la histórica: la posesión, la usucapión.

Hay también hechos que no existen ya. Piénsese en las figuras de la prescripción y de la caducidad de los derechos. O, lo que es más difícil de entender por el no jurista, en la prescripción de los delitos y de las penas ${ }^{32}$. O, por llegar a una todavía mayor dificultad, en la inexistencia de los hechos no contemplados por una sentencia firme y definitiva; es decir, beneficiada por la que en el pasado se dio en llamar «presunción de cosa juzgada».

10. Pero, probablemente, la manifestación más palpable de la «presencia» de los hechos en el mundo del jurista sea su necesidad de tener siempre presente, no un hecho aislado, o unos hechos, sino el complejo conjunto de acontecimientos que conforman la «realidad social».

El artículo 3.1 de nuestro Código civil dice con razón que las normas jurídicas se interpretarán (expresión imperativa), entre otros criterios, conforme al de la realidad social del tiempo en el que han de ser aplicadas ${ }^{33}$.

31 Tengo en mente mi primer conocimiento real de un despacho de abogados (hace poco más de treinta y cinco años), cuando aquellos con quienes aprendí el oficio se las arreglaban con unos pocos códigos y con escuálidos repertorios de legislación. No les imagino hoy sujetos al papel o al ordenador para tener una relativa seguridad sobre la vigencia o no de una disposición, sobre las normas derogatorias de las que todos los días se promulgan, o sobre las concordancias - que muchas veces suelen ser discordancias- entre unas y otras. Y, lo que es más grave, teniendo que acudir al «buscador» del ordenador para, mediante fórmula tan poco «científica», brujulear en el mar normativo que nos ha inundado.

${ }^{32}$ Quienes hayan explicado una asignatura de introducción al Derecho, llámese como se llame en cada momento y lugar, recordarán la intervención de algún o de algunos alumnos que no entienden que un delincuente quede impune porque su delito ha prescrito. E incluso hoy, cuando se sostiene la imprescriptibilidad de ciertas conductas delictivas, vuelven a aparecer los hechos: porque el problema está en determinar qué actos deben o no ser los imprescriptibles.

${ }^{33}$ Criterio que, de acuerdo con la construcción gramatical y lógica del precepto, sólo cede ante el constituido por el espíritu y finalidad de la norma que haya de aplicarse. 
El jurista, por eso, tiene que estar siempre atento a todos los hechos que le rodean. Porque son todos ellos (el conjunto, insisto) los que en mayor o menor medida condicionan las «soluciones» de las que luego hablaré.

Con este criterio, el de la realidad social, la jurisprudencia española de los últimos años ha dado, por decirlo gráficamente, un vuelco a la interpretación de no pocos preceptos, algunos de ellos muy «tradicionales». De otro lado, la realidad social, vista por la doctrina y a veces por la propia jurisprudencia, ha inspirado cambios legislativos, en ocasiones muy radicales ${ }^{34}$.

Creo que Ulpiano diría también ahora lo que dijo entonces.

11. Para terminar este apartado relativo a los hechos, no puedo dejar de mencionar -ahora en un plano filosófico- la moderna orientación, denominada constructivismo, que advierte de la poderosa capacidad del Derecho para definir la realidad, para conformarla. Ya no es tanto cuestión de que el pensamiento jurídico se ocupe de la «fuerza normativa de los hechos», sino de observar que el Derecho «fabrica hechos» ${ }^{35}$.

\footnotetext{
${ }^{34}$ Ahora bien, debe coincidirse con Gullón BALlESTERos, Antonio, en que éste criterio hermenéutico es «peligroso por lo difícil que resulta en numerosos casos comprobar la sujeción a él del aplicador del Derecho», y «se presta a coartada fácil cuando se trata de imponer soluciones de justicia personales: la misma realidad no es valorada y apreciada por todos de la misma forma» (en Comentario del Código civil, obra colectiva coordinada por SIERRA Gil De La Cuesta, Ignacio, $2^{\text {a }}$ ed., Bosch, Barcelona, 2006, p. 98).

${ }^{35}$ Vid. el excelente libro de MARTínez GARCía, Jesús Ignacio, La imaginación jurídica, Debate, Madrid, 1992. Tiene enjundia, por ejemplo, el pasaje en el que el autor dice: «El derecho establece sus propios criterios de existencia decretando que quod non est in actis no est in mundo. Delimita formalmente lo que para él es verdad, estableciendo el principio de que res iudicata pro veritate habetur. Impide la intromisión incontrolada de criterios extrínsecos de realidad mediante presunciones iuris et de iure. Formula definiciones estipulativas que con fines operativos establecen lo que es tal o cual cosa a los efectos de determinada disposición, redefiniendo por medios de nomina iuris el sentido usual de ciertos términos. Hace un uso generalizado de la fictio iuris siempre que las necesidades de la técnica jurídica así lo aconsejen. No podría funcionar sin el principio neminem licet ignorare ius...».

En otro pasaje, pp. 50-51, dice MARTÍnEz GARCÍA: «Los elementos de hecho no son un mero punto de partida proveniente de la realidad objetiva, sino el resultado de operaciones jurídicas que establecen y fijan los hechos y de este modo elaboran el input del derecho. La noción de hecho carece de una existencia autónoma. Por ello se ha señalado que 'el hecho jurídico no es sencillamente el hecho, sino el hecho que existe en y por el derecho'. La determinación de lo que es o no jurídicamente relevante compete exclusivamente al derecho. Se trata de una relevancia interna y, por tanto, de un juego tautológico: es jurídicamente relevante lo que el derecho considera como tal».

Particular interés tiene el capítulo IV, pp. 95 a 117, sobre la ficción jurídica, como expresión del poder de la imaginación en el Derecho. La actividad jurídica es ante todo el despliegue de un formidable esfuerzo imaginativo, es la creación de toda una forma de pensar y de expresarse. La imaginación tiene un papel imprescindible en la génesis y permanencia de las instituciones... el jurista recurre frecuentemente a la metáfora para articular su propio pensamiento y domina una retórica que hace abundante uso de figuras e imágenes, pro-
} 
Cómo no decir esto, si una norma jurídica de la Unión Europea determinó qué se entiende por «queso». O si una Ley española nos dijo qué significa jurídicamente «marisco». O si, sin necesidad de ir más lejos, llamamos «finca», a efectos del Derecho registral, a una vivienda situada en la octava planta de un edificio. La más cabal creación de hechos por el Derecho es, probablemente, la circunstancia de que la Ley española de hipoteca naval (del siglo XIX) declare que el buque es, a efectos de la misma, un bien inmueble; curiosa paradoja en relación con una cosa, el buque, que por definición está llamada a moverse.

Y qué decir de las «presunciones legales», tanto las iuris et de iure como de las iuris tantum, que pueblan el mundo del jurista de «hechos que no son hechos». O de las «ficciones», también frecuentes en el Derecho ${ }^{36}$.

Pero también en el caso de las llamadas «presunciones judiciales» (o del hombre, como antes se decía), el Derecho «crea» hechos. Cuando el artículo 386 de la Ley de Enjuiciamiento civil dispone que a partir de un hecho admitido o probado, el tribunal podrá presumir la certeza de otro hecho (si entre el admitido o demostrado y el presunto existe un enlace preciso y directo, según las reglas del criterio humano), la norma está otorgando al juez - pero también a todo jurista- la posibilidad de «construir» una historia completa, o más completa (siempre en términos figurados) de «lo que ocurrió». Es decir, de los hechos integrantes del conflicto.

vocando una eficaz intersección entre el mundo de la acción y el de la representación. Interpretar el Derecho es imaginar, recrear la literalidad de una norma que puede llegar a adquirir algo así como vida propia. Proponer una legitimación es entre otras cosas fantasear, como bien se ve en el pensamiento contractualista que incorpora una impresionante dosis de irrealidad; mientras que se deslegitima aquello que se desmitifica, aquello que queda privado de ficciones activas y operantes (pp. 96-98).

${ }^{36}$ En la sentencia del Tribunal Supremo de 2 de julio de 1987, primera en la que se otorgó un cierto reconocimiento a la transexualidad, se dijo que «será una ficción de hembra si se quiere, pero el Derecho también tiene su protección a las ficciones. Porque la ficción desempeña en el Derecho un papel tan importante como el de la hipótesis en las ciencias exactas. Una y otra son meras suposiciones que hay que admitir para legitimar determinadas consecuencias en orden a la verdad científica o de la justicia o utilidad social. Sólo partiendo de una hipótesis es posible establecer en ocasiones principios y fundamentar teorías que expliquen todo orden de hechos o fenómenos demostrados por la experiencia; y sólo aceptando una ficción se hace viable en ciertos casos establecer derechos que de otra suerte carecerían de base racional o jurídica en que apoyarse». Añadió luego: «Esta ficción ha de aceptarse para la transexualidad; porque el varón operado transexualmente no pasa a ser hembra, sino que se le ha de tener por tal por haber dejado de ser varón por extirpación y supresión de los caracteres primarios y secundarios y presentar unos órganos sexuales similares a los femeninos y caractereologías psíquica y emocional propias de este sexo». 


\section{Conceptos}

12. Pero el jurista, que piensa y trabaja en «el mundo», con realidades «del mundo», e incluso que lo hace «para este mundo», opera y razona con instrumentos que no son «de este mundo».

Vistas las cosas bajo el prisma de la epistemología ${ }^{37}$, el jurista practica una ciencia ${ }^{38}$, si bien es cierto que, salvo en el terreno académico, no es habitual que piense siquiera en ello ${ }^{39}$. Lo que ocurre es que sus «herramientas» no son cosas perceptibles por los sentidos, sino «conceptos»; en definitiva, palabras. Se trata de esas palabras que nos son imprescindibles, pero que a la vez han dado lugar a las abundantes sátiras de las que hemos sido objeto a lo largo de los tiempos ${ }^{40}$; en parte, por lo que tienen de críptico o «misterioso» para el común de los mortales. No dejan de ser una «jerga», un «argot», que sublevan a quienes se ven en la necesidad de acudir a nosotros, $\mathrm{u}$ oyen lo que dicen las leyes, las sentencias, los abogados.

13. Que alguien diga tener derecho a algo, que exista una sociedad anónima, decidir que un bien de nuestra propiedad tenga un determinado destino después de nuestra muerte, reclamar a quien nos reclama, enjuiciar un tribunal español delitos cometidos en China, pagar un «sobreprecio» por una botella de vino, querer contraer matrimonio poligámico dos marroquíes en España, por ejemplo, son para nosotros conceptos como derecho subjetivo, persona jurídica mercantil, sustitución fideicomisaria, reconvención, juris-

${ }^{37}$ Como es sabido, del griego epistéme, «conocimiento». Hoy se entiende como «doctrina de los fundamentos y métodos del conocimiento científico».

${ }^{38}$ No me adentro, desde luego, en la espinosa cuestión de si el Derecho es ciencia, cuándo lo es y cuándo no (sobre este punto, vid. NiNo, Carlos Santiago, Introducción al análisis del Derecho, edición española, Ariel, Barcelona, 1983, pp. 317-347). Hay autores contemporáneos de obras generales que ni siquiera plantean la cuestión, quizá por considerarla superada (por ejemplo, TerRé, François, Introduction générale au droit, Dalloz, Paris, 1991). Tampoco me enzarzo en la discusión de si hay una ciencia del Derecho, en singular (llamada así, o aun Teoría del Derecho, para evitar los equívocos sobre una identificación con la cientificidad físico-matemática; PÉrEZ LuÑo, Antonio-Enrique, et al., Teoría del Derecho. Una concepción de la experiencia jurídica, Tecnos, Madrid, 1997, pp. 44-45), o si debe hablarse, en plural, de ciencias del Derecho (De Castro y Bravo, Federico, Derecho civil de España, Instituto de Estudios Políticos, I, Madrid, 1955, pp. 63-72).

${ }^{39}$ A diferencia, me parece, de lo que ocurre con el médico cuando trabaja en su hospital o con el químico que lo hace en un laboratorio farmacéutico. Pero es posible que en todas las profesiones basadas en una ciencia, ésta sea una técnica en la aplicación al caso concreto. Vendría a darse de nuevo la dualidad epistéme-téchne. Con todo, no está de más señalar que, reconociéndose a la Medicina como ciencia, por ejemplo, es frecuente que se recurra al concepto de «técnica»; v. gr., cuando se habla de la «técnica» tal o cual para afrontar quirúrgicamente un problema vascular.

${ }^{40}$ Recordemos, en la literatura española, desde Quevedo hasta Jacinto Benavente. 
dicción universal, impuesto indirecto y externalidades negativas ${ }^{41}$, respectivamente.

Conceptos, unidades, principios, instituciones, construcción, sistema ${ }^{42}$, y abundantísimas palabras que de aquéllas derivan «científicamente», son términos que los juristas utilizamos para entender nuestra materia y para entendernos entre nosotros. Pero creo que nos equivocaríamos si pensáramos que son «instrumentos» para conocer qué es lo justo, siendo así que, a mi juicio, son sólo palabras para argumentar por qué es justo ${ }^{43}$. Si no fuera de este modo, estaríamos haciendo abuso (no uso) o caricatura del lenguaje jurídico.

Los conceptos están en estrecha relación con las normas jurídicas, esto es, como solemos decir, las leyes. En ocasiones, son estas últimas las que inspiran o sugieren conceptos jurídicos. Otras veces, al revés, los conceptos acuñados por los autores encuentran acogida en la legislación; no es infrecuente que los juristas digamos que tal o cual concepto ha sido «consagrado» (palabra muy reveladora) en el artículo tal o cual de la Ley equis.

\footnotetext{
${ }^{41}$ Propongo este «concepto» porque es el último que he conocido, siendo ajeno a mi disciplina; en concreto, es propio, y nuevo, del Derecho internacional privado. Vid. CARRASCOSA GONZÁLEZ, Javier, «Orden público internacional y externalidades negativas», Boletín de Información (Ministerio de Justicia), número 2065, 15 de julio de 2008, pp. 2351-2378. Los conceptos se están «creando» constantemente. Hoy nos son familiares algunos impensables hace dos siglos; por ejemplo, acto administrativo, delito imposible, suelo no edificable (y los demás conceptos del insondable mundo del Derecho urbanístico), relación laboral, pareja de hecho; y, todavía más fantasmagórico, «matrimonio» entre dos personas del mismo sexo.

${ }^{42}$ Algunas de estas palabras, bien se ve, proceden del lenguaje de las ciencias físicomatemáticas, por el entusiasmo que estas últimas inspiraron a la dogmática alemana del siglo XIX.

${ }^{43}$ Pero hay que tener en cuenta la circunstancia de que la vida social está repleta de ingredientes que nada tienen que ver, en principio, con el Derecho; por ejemplo, políticos o económicos. Sólo con conceptos jurídicos, no podría explicar nadie al arrendador de una vivienda, en la España de los años 50, que su arrendamiento, concertado por cinco años, quedara automáticamente prorrogado por ley durante la vida del arrendatario e incluso durante dos generaciones más, y con una renta prácticamente constante; dicho en términos coloquiales, congelada. Y ha tenido que ser un concepto nuevo (el de la «jurisdicción universal») el que permita explicar un caso que antes he citado: la sentencia del Tribunal Constitucional español de 22 de octubre de 2007 declaró vulnerado el derecho de los demandantes de amparo a la tutela judicial efectiva, en su vertiente de derecho de acceso a la jurisdicción, siendo así que esos demandantes habían interpuesto querella criminal contra varios ciudadanos chinos (dirigentes), por delitos de genocidio y torturas cometidos en China desde el año 1990 por la persecución de personas pertenecientes o simpatizantes de un determinado grupo. Se da la circunstancia de que la Sala Segunda, de lo Penal, del Tribunal Supremo, había declarado, en sentencia de 18 de marzo de 2005, no haber lugar al recurso de casación contra el auto de la Audiencia Nacional que confirmó una previa resolución declarativa de no ser procedente la admisión a trámite de la querella.
} 
14. La «construcción científica» del Derecho (por seguir con nuestro lenguaje, cosas que no son de este mundo), o -dicho de otro modo- la «doctrina», constituye, junto con los hechos, la vida misma del jurista. Siempre fue así, pero en la actualidad lo es de forma más intensa que nunca.

Si hablaba antes de la catarata de la legislación, tratándose de doctrina podríamos referirnos a un verdadero «océano». Porque la bibliografía jurídica de nuestros días es verdaderamente arrolladora. En cualquier sector del Derecho, la literatura científica aumenta día a día y, además, en términos que bien podríamos calificar como de progresión geométrica. Proliferan las publicaciones de todo tipo, desde los tratados hasta los manuales, pasando por las monografías y las revistas científicas. Y estos dos últimos «géneros» alcanzan elevadas cotas de especialización. De suerte que el «mundo» del jurista es hoy, incomparablemente más que en el pasado, un incesante acopio de información bibliográfica, no siempre encaminado a buscar una «respuesta» al concreto caso que en cada momento le ocupa ${ }^{44}$.

\section{Soluciones}

15. He dicho al comienzo que no pretendía filosofar sobre el Derecho. Hacerlo sería tanto como tomar postura sobre su esencia, sobre su justificación o razón de ser y sobre sus funciones.

Por eso, para mantenerme en el más modesto plano «existencial», que he anunciado, termino mis palabras con lo que probablemente sea el único elemento común a la experiencia y al vivir de todo jurista, académico o práctico.

Me refiero al «desenlace» que está siempre en la mente del jurista, esto es, en «su mundo».

Hablo, claro está, de la «solución» que inspira nuestro quehacer. Es, sobre todo, en el caso del abogado, o de cualquier otro «práctico» del Derecho (los hoy ominosamente llamados «operadores jurídicos»), incluyendo al juez. La «solución» es la sentencia, en el sentido más amplio de la palabra.

${ }^{44}$ No es éste momento ni lugar para expresar juicios sobre la bibliografía jurídica actual. Pero, además de dejar constancia de su formidable volumen, que se expresa en el grosor de los catálogos editoriales y que hace dificilísimo el empeño de estar al día en las publicaciones, incluso en las que constituyen el área de conocimiento más «familiar» para cada uno, quizá interese poner de relieve -desde la perspectiva de un jurista europeo- el muy especial relieve que hoy se atribuye a la jurisprudencia. Quizás se trate, al menos en parte, de un reflejo del cada día mayor impacto de los «modos de pensar» de los juristas del common law en los del Derecho escrito. Impacto que, según me parece, también se da en sentido contrario; dicho de otro modo, es recíproco. Es igualmente un signo de la bibliografía actual, sobre todo la «académica», la presencia de notables dosis de Derecho comparado; o, $\sin$ ir tan lejos, de Derecho extranjero. 
Uso el vocablo «solución» (no el de resolución, a pesar del parentesco etimológico de ambos términos), porque el primero es el que expresa, a mi juicio con más precisión, lo que quiero decir. Y tampoco acudo a la palabra «decisión», porque podría entenderse que me refiero también a la elaboración de las normas jurídicas, esto es, a la legislación en el sentido más amplio del concepto, incluyendo los reglamentos de la Administración. Y si no hablo de este fenómeno, el de crear normas, es, en primer lugar, por su natural carácter de generalidad, que excluye la contemplación de cada caso concreto; y en segundo término, porque aunque las Administraciones Públicas están hoy integradas por auténticas mesnadas de juristas, éstos no son los que tienen en su mano lo que debe disponerse: suelen ser los políticos los que lo hacen por ellos.

Solución, del solvo, solvere, se ajusta a la primera acepción latina del verbo, esto es, «soltar», «desatar»; como se hace con un nudo.

Porque, en efecto, la sentencia «desata» el nudo de un conflicto, de una controversia, que en definitiva son «ataduras». Como no podía ser de otro modo, ya el latín clásico aplicó el solvere, en sentido figurado, como disipar o deshacer; por ejemplo, un dubium, una duda. Feliz acepción, en nuestro caso, porque el «mundo» del jurista es un mundo de dudas, de incertidumbres, de incógnitas ${ }^{45}$.

Verdad es que esto depende en parte de una visión determinada del Derecho, pero sigue siendo cierto. Aún más, no falta quien entiende que Derecho (ius), en cuanto resultado de un iudicium, es «lo que declaran los jueces» (ius, quod iudex dicit) ${ }^{46}$.

Igualmente, el abogado o el funcionario, cuando asesoran o cuando sostienen una tesis, están pensando en términos de solución, aunque con la diferencia (práctica, no conceptual) de que su solución queda sometida a otra «superior» ${ }^{47}$.

Pero también el estudioso del Derecho, el «académico», al margen de un conflicto real, es víctima de la duda, de la incertidumbre. Su objetivo es también una «solución». La diferencia reside ahora en que él puede proponer diversas «soluciones»; alternativas y -además- incluso contradictorias entre sí.

${ }^{45}$ Incluso para el propio juez, antes del momento de dictar su solución-resolución.

${ }^{46}$ D'ors, Álvaro, Una introducción ..., cit., pp. 108-111. Escribió el eminente romanista que, a tal efecto, cuando, por ejemplo, un alumno emite su opinión en una clase práctica sobre un caso hipotético, esa opinión asume el carácter de una sentencia judicial, aunque esta actividad no tenga, naturalmente, ni la eficacia ni la repercusión social que tiene la sentencia de un juez en el ejercicio propio de sus funciones.

${ }^{47}$ Recuérdese lo frecuente que es, en escritos forenses o administrativos, que se haga reserva de «salvo mejor criterio» o de «su superior criterio». 
16. La duda debe conducir a la prudencia.

Esta palabra está muy unida al Derecho. En los textos clásicos se encuentra con frecuencia, muchas veces en la expresión prudentia iuris. Y ha dado o da nombre, con el bello vocablo «jurisprudencia», a algunas Facultades de Derecho y a Academias de juristas.

Es también frecuente que el término se use en el sentido de virtud intelectual para distinguir lo bueno de lo malo, previa a otra virtud cardinal, la justicia, como dar a cada uno lo suyo.

Pero yo quiero referirme aquí a otra «prudencia». Es la que los diccionarios latinos sitúan habitualmente como primera acepción de prudentia, esto es, la de «previsión», procedente de providere. El prudens es «el que prevé», el que «sabe de antemano» y actúa con conocimiento de causa ${ }^{48}$.

Porque, en efecto, así como se ha dicho con acierto que «contratar es prever», la vida toda del jurista gira en torno a la previsión de las «soluciones» de las que ahora estoy hablando. La expresión más cabal de esto es, sin duda, lo que el abogado prevé que va a ser la resolución judicial del asunto en el que interviene.

Pero es probable que la manifestación más patente del prever, en el caso de cualquier individuo, esto es, de toda persona, sea la de actuar de una manera determinada, «en previsión» de las consecuencias (sobre todo las negativas) que le deparará hacerlo de otro modo ${ }^{49}$.

Esto, cuando se trata del jurista, se traduce muchas veces en llegar a soluciones sin contienda judicial. La previsión hará que en su función de dictamen, asesoramiento o consejo, esté sujeto a la máxima exquisitez en el difícil proceso intelectual de predecir, proceso en el que la imaginación reviste una importancia decisiva. Así, cuando redacta un contrato o un testamento, elabora los estatutos de una sociedad o recomienda una transacción ${ }^{50}$.

Es esto lo que me mueve a mencionar de nuevo el problema de la «certeza» del Derecho, que en definitiva es hablar de la seguridad jurídica, uno de los pilares de lo que llamamos Estado de Derecho o imperio de la ley ${ }^{51}$.

\footnotetext{
${ }^{48}$ Primera acepción, por ejemplo, en Segura Munguía, Santiago, Nuevo diccionario ..., cit.

${ }^{49}$ A esto me referí en mi trabajo «Sobre las palabras 'responder', 'responsable' y 'responsabilidad'», en la obra colectiva Estudios jurídicos en homenaje al Profesor Luis DiezPicazo, Civitas, Madrid, 2003, II, pp. 1323-1352. Es justamente aquí cuando el Derecho manifiesta su función más noble y su mayor eficacia. Es cuando sus normas son espontáneamente cumplidas, en términos estadísticos elevados. Es el Derecho visto como pura regla de conducta o como instrumento de organización social. Y es lo que hace que sea una perspectiva parcial, aunque yo la haya citado antes, la que enlaza al Derecho (y, por ello, al jurista) con el fenómeno del «conflicto».

${ }^{50}$ En este último caso, nunca sabrá, por principio, si su previsión fue acertada o no.

${ }^{51}$ Extremo sobre el que escribí hace muchos años (1974) en mi libro Introducción al estudio del Derecho, titulado luego Una teoría del Derecho (introducción al estudio del Derecho), cuya $6^{\mathrm{a}}$ edición, con posteriores reimpresiones, fue en Editorial Civitas. Me estoy
} 
17. Pero no voy a insistir en esto, para no incurrir en tópicos, y menos ante este auditorio.

Quiero referirme a otro «elemento» del quehacer del jurista -al menos como ideal- que es la sindéresis. Y no se alarmen por el cultismo, porque se trata simplemente (pero nada menos) que de la sensatez, también conocida por «sentido común».

Dice sabiamente nuestro Diccionario ${ }^{52}$ que sindéresis es «discreción, capacidad natural para juzgar rectamente ${ }^{53}$. Guarda estrecha relación con «sentido común», que, también según nuestro Diccionario, es «buen juicio natural de las personas» ${ }^{54}$. Es el buen sentido del que Descartes decía ser la cosa del mundo mejor repartida, porque todos piensan estar tan bien provistos o dotados de él, que incluso quienes se muestran más reacios a considerarse satisfechos en relación con cualquier otra cosa, no suelen desear más (de buen sentido) que el que ellos tienen ${ }^{55}$.

He pensado muchas veces que es lástima que la «sensatez» no pueda ser objeto de nuestros planes de estudios ${ }^{56}$. No digo que no pueda «aprenderse», porque, a pesar de que el Diccionario habla de «capacidad natural», no creo que haya que aceptar que se nace y se muere con ella o sin ella. Más aún, la carrera de Derecho está de ordinario organizada para que el sentido común

refiriendo ahora a las páginas 60-62 y 80-83 de la última edición reimpresa, Madrid, 1993. Y es digno de lectura el trabajo de PÉREZ LuÑo, Antonio-Enrique, «La seguridad como función jurídica», en Funciones y fines del Derecho (estudios en honor del Profesor Mariano Hurtado Bautista), Universidad de Murcia, Murcia, 1992, pp. 273-289.

${ }^{52}$ Es el Diccionario de la Lengua Española, Real Academia Española, 22 a ed., Madrid, 2001.

${ }^{53}$ Ésta es la traducción que del vocablo griego syntéresis se encuentra en los diccionarios de griego-español; por ejemplo, en EsEVERRI HuALDE, Crisóstomo, Diccionario etimológico de helenismos españoles, Pampilonensia, Pamplona, 1945. Procede del verbo griego synteréo, que significa, entre otras cosas, «observar estrictamente» o «preservar». Para la voz synteréo, en A Greek-English Lexicon, de LidDELl y ScOTT, Clarendon Press, Oxford, 1968 , se dice de ese verbo que significa, entre otras cosas, conservar o preservar cuidadosamente (quiere decir, una norma o un principio).

${ }^{54}$ Creo que interesa señalar, porque al menos es curioso, que la primera acepción de «juicio» en el Diccionario es la de «facultad del alma, por la que el hombre puede distinguir el bien del mal y lo verdadero y lo falso». Muy anterior al significado de «proceso judicial». Por otro lado, la palabra «discreción», asimismo en su primera acepción del Diccionario, significa «sensatez para formar juicio y tacto para hablar u obrar»; lo que explica el tan frecuente uso en la forma de adjetivo («discreto» y «discreta») en el Siglo de Oro de la literatura española.

${ }^{55}$ Es en el comienzo mismo del Discurso del método. Lo tomo de uno de los libros que recoge las obras del genial filósofo francés: Descartes, Euvres philosophiques, Garnier, París, 1963, Tomo I, p. 568. El anotador del libro, AlquiÉ, considera que la referida expresión de Descartes es irónica. Hubiera o no ironía en esas primeras palabras, Descartes escribió poco después, en el mismo pasaje, que el buen sentido es la facultad de juzgar bien, y de distinguir lo verdadero de lo falso.

${ }^{56}$ Y que no sea un criterio para la designación de los jueces. 
vaya impregnando la mente de los estudiantes. A estos efectos, la «lógica» del Derecho romano (salvados los primitivismos y las particularidades de su dilatada duración), la de la Parte General del Derecho civil, así como la de las partes generales del Derecho de obligaciones y del Derecho de cosas, cuando están bien expuestas, pueden ser eficaces instrumentos para desarrollar la sindéresis.

Y si acudo a estos conceptos es porque, a mi entender, la primera condición que debe tener una solución en Derecho es la de que sea sensata, de sentido común, presidida por la sindéresis.

No creo equivocarme al decir que una construcción conceptualmente correcta (en lo que tiene de «discurso») puede ser un adefesio si no resiste el «común sentido», esto es, el de la generalidad de los mortales.

Todos conocemos, me parece, escritos forenses, sentencias (y, desde luego, leyes o reglamentos) en los que la sindéresis brilla por su ausencia.

18. La búsqueda de la solución -naturalmente, no digo hallarla ${ }^{57}$ - constituye un notable desafío; por un lado está el saber técnico o dominio de los «conceptos»; y por otro, la sensatez, el sentido común, la sindéresis ${ }^{58}$.

Ahora bien, para el jurista en general, pero muy particularmente para el «práctico del Derecho», la argumentación basada en la sensatez tiene un inconveniente a priori, que es el de que su modo de razonar entre en colisión con una manera de pensar inspirada sólo en los criterios que llamamos dogmáticos o conceptuales. Dificultad que también siente el jurista «académi-

\footnotetext{
${ }^{57}$ Por razones obvias. Entre ellas, porque dos juristas sin interés personal en un caso pueden llegar a dos distintas soluciones. El mejor ejemplo es el de una sentencia revocada en un recurso. También por motivos evidentes, no llamo jurista al legislador; primero, porque la norma jurídica, por su intrínseca generalidad, encuentra dificultades para dar respuesta (que es solución) a los tan variados casos que la realidad ofrece; segundo, porque su razonabilidad, sindéresis dicho de otro modo, sólo puede enjuiciarse a posteriori; tercero, porque no acabo de ver claro a qué nos referimos cuando hablamos del «legislador» en los sistemas parlamentarios y administrativos de nuestros días (en concreto, ¿qué es la voluntas legislatoris?).

${ }^{58}$ A estos efectos, y en concreto en relación con la solución por antonomasia, que es la sentencia (palabra, por cierto, cuya primera acepción en nuestro Diccionario es la de «dictamen o parecer que alguien tiene», antes que «resolución del juez», acepción tercera), es clara la diferencia entre las que dictan los tribunales del common law y las pronunciadas por los del que llamamos área del civil law o Derecho escrito. Aquéllos están muy poco «sujetos a la ley», se encuentran vinculados por el «precedente» mucho menos de lo que solemos decir, y tratan de «convencer» con razonamientos en los que, sin faltar «conceptos», pero de ordinario no muy abundantes, hay como inspiración principal la «lógica natural», la razonabilidad; en suma, la prudencia en su significado de «sensatez, buen juicio». Tengo en mente, por ejemplo, las sentencias dictadas por tribunales ingleses en los llamados y célebres «casos de la Coronación», a comienzos del siglo XX. Vid. ESPERT SANZ, Vicente, La frustración del fin del contrato, Tecnos, Madrid, 1968, en su primera parte.
} 
co»; cuántas veces no habremos visto, al analizar una sentencia o una obra ajena, para un trabajo doctrinal, el escollo del que hablo.

Puedo proponer el ejemplo de la solidaridad en el caso de daño extracontractual causado por varios agentes, que es solución sensata pero que no está en nuestro Código civil. Felizmente, acabó aceptándola una también sensata jurisprudencia de hace unas tres décadas. Lo mismo podría decirse de la «solución» llamada compensación de culpas, que tampoco está en el Código civil y que en un plano dogmático no se encuentra exenta de dudas (por ejemplo: ¿puede haber «culpa» concurrente en un niño de siete años?).

19. La relatividad de las soluciones en el Derecho (relatividad que sólo deja de serlo -lamentablemente para él- para el sujeto concreto que se ve obligado a soportar las consecuencias de una también concreta sentencia judicial firme) se muestra inequívocamente a partir de la afirmación teórica o conceptual de que en los problemas jurídicos no existe un procedimiento generalmente aceptado ni un criterio seguro para saber si la solución es adecuada, por lo que no suele haber consenso sobre la corrección de los resultados ${ }^{59}$. Y esto, sin contar con que, con toda legitimidad, e incluso con plena convicción, un jurista pueda verse movido por un interés. Es obvio el caso del abogado, a quien incumbe, sobre todo cuando se trata de un proceso, sostener una tesis determinada. Pero es que, incluso sin mediar ningún interés, bien puede suceder que la específica formación de cada jurista le lleve a adoptar puntos de vista no coincidentes con los de otros, en presencia ambos de un mismo caso.

Y es también la relatividad de las soluciones jurídicas la que puede dar, y de hecho da, lugar a un fenómeno que acaso a los juristas no asombre demasiado (por mucho que nos perturbe), pero que al hombre de la calle -no digamos si es parte en un proceso- puede causar escándalo e indignación; en definitiva, una radical desconfianza hacia el Derecho y hacia quienes a él nos dedicamos.

Me refiero al hecho de que un mismo problema sea objeto de soluciones diferentes, en una misma época, por parte de dos órganos judiciales del mismo grado o «jerarquía». Y aun más, que la divergencia de las soluciones se dé en un mismo tribunal ${ }^{60}$.

\footnotetext{
${ }^{59}$ Vid. Gallego Del CAmpo, Germán, «La resolución de problemas jurídicos», en Revista Crítica de Derecho Inmobiliario, número 708, julio-agosto 2008, pp. 1477-1495.

${ }^{60}$ Sobre este extremo, es muy ilustrativa la monografía de Blasco Gascó, Francisco de Paula, La norma jurisprudencial (nacimiento, eficacia y cambio de criterio), Tirant lo Blanch, Valencia, 2000. Y a estos efectos, no puedo dejar de mencionar la novedad de que en los últimos años se venga produciendo con cierta frecuencia, en diversas Salas del Tribunal Supremo español, la fórmula de sentencias dictadas por el Pleno, esto es, por todos los Magistrados integrantes de cada Sala. Una publicación colectiva que acaba de aparecer, y en la que he tenido el honor de participar, se hace eco del significado (o al menos de la intención) de esta práctica: YzQuierdo Tolsada, Mariano (director), Comentarios a las sentencias de unificación de doctrina (civil y mercantil), volumen $1^{\circ}$ (2005-2007), Dykinson, Madrid, 2008.
} 
En suma, forma parte del mundo del jurista (insisto en que ésta es mi perspectiva ahora, no la de la ciencia del Derecho) la circunstancia de que, encaminada como está su vida a proponer soluciones, éstas se encuentren rodeadas por un halo de incertidumbre. Halo, quiero decir, en el sentido natural de la palabra; o sea, el que sugiere la luz difusa en torno de un cuerpo luminoso.

No sé si exagero, pero es posible que la incertidumbre constituya el más hondo sentimiento, a la vez atractivo y desafío, del que vengo llamando mundo del jurista.

20. Pero, y regreso al principio, vuelven a estar presentes los hechos.

La solución fundada en los conceptos, y la que deriva del juicio de lo razonable, exige conocer los hechos en su integridad, cosa que no siempre está a nuestra disposición ${ }^{61}$.

Esa misma razonabilidad (de nuevo la sindéresis) es la que, sin conocer más datos que los que proporciona la sentencia, mueve a dudar de la sensatez de una muy reciente, de una Audiencia Provincial española, que condenó a una agencia de viajes a indemnizar «por daño moral» a una pareja que, habiendo contratado su viaje de novios en la República Dominicana, vio arruinada su luna de miel por un huracán en aquel país. ¿Sensato?, ¿razonable? Dejo a ustedes las conjeturas y las apreciaciones ${ }^{62}$.

${ }^{61}$ Muchas sentencias, en España, son extremadamente lacónicas en la narración fáctica, lo que hace que el uso de los conceptos por parte de la propia resolución sea inmune o casi inmune a la crítica. Por ejemplo, nuestro Tribunal Supremo dictó una sentencia, de 21 de mayo de 2001, en la que se condenó a la sociedad propietaria de una sala de fiestas a indemnizar los daños y perjuicios sufridos por una persona que como cliente se encontraba en ella, al impactar en su ojo derecho un vaso de vidrio u otra cosa del mismo material. Se desconoció la trayectoria del objeto arrojado, así como la identidad de la persona que realizó la acción y si ésta fue intencionada o negligente. Me parece que no es fácil combatir la decisión de la Sala (basada, a mi juicio erróneamente, en el artículo 1.910 del Código civil -parecido al artículo 1119, párrafo tercero, del Código civil argentino-, a su vez inspirado en la actio de effusis vel deiectis, que a mi entender se fundamenta en una posición de «control» por parte del propietario del edificio), si no es argumentando que la sala de fiestas contaba con un «razonable» número de empleados (evidentemente, no tantos como clientes), destinados a vigilar el comportamiento de los asistentes al local.

${ }^{62}$ A mí se me ocurre: ¿es que la pareja en cuestión no lee los periódicos, ni ve la televisión, como para saber que las tormentas tropicales y los huracanes son «naturales» en aquella parte de la tierra y en ciertas épocas del año? ¿En qué medida podemos esperar que un contrato sea el remedio de todas nuestras adversidades? Sobre esta sentencia, y sobre otras en las que se razona con criterios de «daño moral», recae el fino e incisivo análisis del Profesor DíEZ-PICAZo en su monografía El escándalo del daño moral, actualmente en proceso de edición, Editorial Civitas. Agradezco al autor su amabilidad al haberme proporcionado el original en pruebas de imprenta. 
21. Y ahora doy otro paso más hacia atrás. Vuelvo a la sensatez en la vida del jurista.

Propongo la posibilidad de que acaso sea esa sensatez la que, quizá sin darnos cuenta nosotros mismos, haga que, en presencia de un caso, nos formemos pronto una idea de su solución.

Acostumbramos a decir que el jurista realiza una operación mental de «subsunción» del problema en una o varias normas jurídicas, para así dar una «respuesta».

Yo no diré que no sea así el «desenlace». Lo que ocurre es que el jurista, que al plantearse una cuestión no puede desprenderse de su condición y de su formación, está, inevitablemente, haciendo uso de su sindéresis, unida al saber teórico, para hacerse enseguida una idea de $s u$ «solución». Sería después cuando «construyese» una argumentación que, diríamos, fuera «jurídicamente pura» ${ }^{63}$. A no ser, desde luego, que conociese más tarde «hechos» que antes ignoraba; lo cual, por cierto, no sólo no destruye mi proposición, sino que la robustece, puesto que valorar el significado del «hecho nuevo» puede ser también un acto de aplicación instintiva o intuitiva de la «sensatez».

Formada una primera apreciación (un juicio), la técnica jurídica podría conducir a «matices» de la solución, pero no a desviarse de lo medular en ella ${ }^{64}$.

En mi particular experiencia, creo que esto me ha ocurrido muchas veces, tanto ante un caso real como en presencia de un caso académico. $\mathrm{Y}$ es lo que he oído a no pocos colegas, incluido algún juez.

Podría parecer con esto que estoy «relativizando»o «desmitificando» la sensatez en el Derecho, puesto que tal virtud no es patrimonio exclusivo del jurista $^{65}$, y puede suceder -como decía antes- que dos juristas con la misma formación y en condiciones de total independencia lleguen a soluciones diferentes.

O, al contrario, podría parecer que lo «relativizado» o «desmitificado» por mí es el conocimiento teórico del Derecho, por las mismas razones que acabo de decir.

Pero no creo que sea así. Simplemente, y es lo que he querido decir, se pone de manifiesto que lo razonable y lo conceptualmente correcto no son valores absolutos o incontestables, salvo en casos de soluciones jurídicas

${ }^{63}$ A veces, cuando interesa (pienso en el abogado), puede tratarse de una construcción conceptual de signo diferente de la que a él le convence.

${ }^{64}$ Innecesario es decir que no me estoy refiriendo a un «prejuicio», porque este vocablo entraña, por definición, un defectuoso conocimiento del «objeto».

${ }^{65}$ Conozco a algunos que, siempre a mi juicio, no hacen gala de ella en demasía; del mismo modo que me he encontrado con no juristas altamente dotados de sentido común para cuestiones de Derecho. 
esperpénticas, grotescas o, sin más, que un ciudadano medio no podría comprender $^{66}$.

22. Cuando me he referido a la justicia, no he querido filosofar sobre ese concepto como valor o como principio, sino que he pretendido contemplar lo que al jurista le suele importar más, esto es, la justicia del caso concreto: la justicia material, como solemos decir ${ }^{67}$.

En tanto en cuanto sea ése el objetivo, creo que debe compartirse la idea $^{68}$ de que, sin incurrir en posturas férreamente dogmáticas, las soluciones deben buscarse con una adecuada combinación de conceptos construidos con una razonable dosis de rigor y, además, con sensatez. No siempre es fácil la combinación, pero creo que debemos perseguirla constantemente ${ }^{69}$.

\section{3. $Y$ termino ya.}

Lo hago para reconocer algo que quizá hayan advertido ustedes ya: la escasa presencia, en este discurso, del gran «protagonista» del Derecho, que es la sociedad.

\footnotetext{
${ }^{66}$ Es decir, encontrar como «justificada o natural» (Diccionario).

${ }^{67}$ En relación con la justicia como valor superior del ordenamiento jurídico, según el artículo 1.1 de la Constitución Española, menciono la opinión de mi compañero de Claustro, el Profesor Manuel María ZorRiLla RuIZ, cuando sostiene que tal valor no sólo se halla dentro del ordenamiento, sino que prima sobre la Constitución misma y el resto del ordenamiento jurídico. La aplicación de cualquier norma jurídica exigiría, de seguirse esta línea, un control inicial consistente en verificar si la norma es justa, porque así se desprende de una de las lecturas legítimas del artículo 1.1 de la Ley Fundamental. Lo notable de este control es que se antepone, en nombre de una suerte de moralidad legalizada, al de la validez de la norma, más allá de la cual no permite ir el positivismo legalista. Estas ideas, añade ZoRRILla RuIZ, pueden definir una postura, avalada por la Constitución, por la que ésta sigue siendo la norma suprema del ordenamiento jurídico, siquiera se hallen, por encima de ella y dentro del mismo ordenamiento, los principios informadores que, en cada momento, reflejan los contenidos variables del valor superior de la justicia material. Tomado del trabajo Preferencias y oportunidades moralizadoras en la aplicación judicial del Derecho, para una obra colectiva, en proceso de publicación, promovida por el Consejo General del Poder Judicial.

${ }^{68}$ Que está implícita en DíEZ-PicAzo, El escándalo..., cit.

${ }^{69}$ No me dejo llevar por mis infinitos sentimientos de cariño, agradecimiento y admiración - por este orden- cuando, en relación con lo que acabo de decir, pienso en mi maestro, el Profesor Antonio Gullón Ballesteros. Sin necesidad de referirme a su obra científica, que tampoco necesita mis opiniones, hablo del Gullón de los últimos años, como Magistrado de la Sala de lo Civil del Tribunal Supremo. Sus ponencias en tantas y tantas sentencias constituyen, a mi entender y al de todos los colegas (profesores y abogados) cuyas opiniones he oído, un verdadero modelo de la no fácil combinación que menciono arriba. Las considero un ejemplo de saber determinar con máxima precisión qué hecho o hechos constituyen la médula de la controversia en cada caso. También, de hacer uso de una técnica jurídica en la que no hay ni oscuridades ni vacíos; es decir, perfecta. Y de saber aderezar todo ello con una particular finura en la conciliación entre lo que «dicen los conceptos» y lo que reclama un fallo ajustado a la sindéresis.
} 
Pero reitero algo que antes he apuntado: que lo que la sociedad puede y debe esperar es que el «mundo de los juristas» no sea, en cada uno de ellos, una peripecia vital, ni una profesión, y ni siquiera una serie de bienintencionadas ilusiones, sino un «factor» de soluciones guiadas por la búsqueda de una convivencia armónica. Soluciones en las que la libertad y la igualdad hagan posible la justicia; éste es el género próximo del que aquéllas (la libertad y la igualdad) son las dos especies que lo integran.

24. Oí en su día a otro jesuita, buen latinista ${ }^{70}$, un dicho que procedía de su teologado: Lectio brevis. Perfecta si brevis. Perfectior si brevior. Perfectissima si brevissima.

Espero que ésta, al menos, haya sido brevis ${ }^{71}$.

${ }^{70}$ El Profesor Juan Luis Cortina Iceta.

${ }^{71}$ Pero no para suponer que se trate de una obra «perfecta», en el sentido de «excelente en su línea», según nuestro Diccionario de español, sino apelando al significado estricto del perfectus latino. Es decir, consumado, acabado, finalizado. 